\title{
Front Matter: Volume 6544
}

, "Front Matter: Volume 6544," Proc. SPIE 6544, Technologies for Synthetic Environments: Hardware-in-the-Loop Testing XII, 654401 (3 May 2007); doi: 10.1117/12.740775 SPIE. Event: Defense and Security Symposium, 2007, Orlando, Florida, United 


\section{PROCEEDINGS OF SPIE}

\section{Technologies for Synthetic Environments: Hardware-in-the-Loop Testing XII}

Robert Lee Murrer, Jr.

Editor

10 April 2007

Orlando, Florida, USA

Sponsored and Published by

SPIE-The International Society for Optical Engineering

Volume 6544

(5P|F) The International Society

for Optical Engineering

Proceedings of SPIE-The International Society for Optical Engineering, 9780819466662, v. 6544

SPIE is an international technical society dedicated to advancing engineering and scientific applications of optical, photonic, imaging, electronic, and optoelectronic technologies. 
The papers included in this volume were part of the technical conference cited on the cover and title page. Papers were selected and subject to review by the editors and conference program committee. Some conference presentations may not be available for publication. The papers published in these proceedings reflect the work and thoughts of the authors and are published herein as submitted. The publisher is not responsible for the validity of the information or for any outcomes resulting from reliance thereon.

Please use the following format to cite material from this book:

Author(s), "Title of Paper," in Technologies for Synthetic Environments: Hardware-in-the-Loop Testing XII, edited by Robert Lee Murrer, Jr., Proceedings of SPIE Vol. 6544 (SPIE, Bellingham, WA, 2007) Article CID Number.

ISSN 0277-786X

ISBN 9780819466662

Published by

SPIE-The International Society for Optical Engineering

P.O. Box 10, Bellingham, Washington 98227-0010 USA

Telephone 1 360/676-3290 (Pacific Time) · Fax 1 360/647-1445

http://www.spie.org

Copyright (@ 2007, The Society of Photo-Optical Instrumentation Engineers

Copying of material in this book for internal or personal use, or for the internal or personal use of specific clients, beyond the fair use provisions granted by the U.S. Copyright Law is authorized by SPIE subject to payment of copying fees. The Transactional Reporting Service base fee for this volume is $\$ 18.00$ per article (or portion thereof), which should be paid directly to the Copyright Clearance Center (CCC), 222 Rosewood Drive, Danvers, MA 01923. Payment may also be made electronically through CCC Online at http://www.copyright.com. Other copying for republication, resale, advertising or promotion, or any form of systematic or multiple reproduction of any material in this book is prohibited except with permission in writing from the publisher. The CCC fee code is 0277$786 \times / 07 / \$ 18.00$.

Printed in the United States of America. 


\section{Contents}

$\checkmark \quad$ Conference Committee

\section{SESSION 1 INFRARED PROJECTOR DEVICE DESIGN/CHARACTERIZATION/OPTIMIZATION}

654402 Spectral radiant emission of dynamic resistive arrays [6544-01]

M. Brown, A. G. Hayes, K. Anderson, MIT Lincoln Laboratory (USA); J. James, Santa Barbara

Infrared, Inc. (USA); D. C. Harrison, MIT Lincoln Laboratory (USA)

654403 Resistor array infrared projector nonuniformity correction: search for performance improvement II [6544-02]

L. Świerkowski, R. A. Joyce, O. M. Williams, Defence Science and Technology Organisation (Australia)

654404 Large format resistive array (LFRA) infrared scene projector (IRSP) performance and production status [6544-03]

J. Oleson, J. James, J. LaVeigne, K. Sparkman, G. Matis, S. McHugh, Santa Barbara Infrared, Inc. (USA); J. Lannon, S. Goodwin, A. Huffman, RTI International (USA); S. Solomon, Acumen Scientific (USA)

654405 OASIS: cryogenically optimized resistive arrays and IRSP subsystems for spacebackground IR simulation [6544-04]

J. James, J. LaVeigne, J. Oleson, G. Matis, Santa Barbara Infrared, Inc. (USA); J. Lannon,

S. Goodwin, A. Huffman, RTI International (USA); S. Solomon, Acumen Scientific (USA);

P. Bryant, Left Coast Consulting (USA)

\section{SESSION 2 HWIL FACILITIES}

654408 Air Force Electronic Warfare Evaluation Simulator (AFEWES) infrared test and evaluation capabilities [6544-07]

H. D. Jackson II, T. L. Blair, B. A. Ensor, U.S. Air Force (USA)

654409 Hybrid Infrared Scene Projector (HIRSP): a high dynamic range infrared scene projector [6544-21]

T. M. Cantey, D. B. Beasley, Optical Sciences Corp. (USA); J. Buford, H. Kim, G. Ballard, U.S.

Army Aviation and Missile Research, Development, and Engineering Ctr. (USA)

Pagination: Proceedings of SPIE follow an e-First publication model, with papers published first online and then in print and on CDROM. Papers are published as they are submitted and meet publication criteria. A unique, consistent, permanent citation identifier (CID) number is assigned to each article at the time of the first publication. Utilization of CIDs allows articles to be fully citable as soon they are published online, and connects the same identifier to all online, print, and electronic versions of the publication. SPIE uses a six-digit CID article numbering system in which:

- The first four digits correspond to the SPIE volume number.

- The last two digits indicate publication order within the volume using a Base 36 numbering system employing both numerals and letters. These two-number sets start with 00, 01, 02, 03, 04, 05, 06, 07, 08, 09, 0A, OB ... 0Z, followed by 10-1Z, 20-2Z, etc. The CID number appears on each page of the manuscript. The complete citation is used on the first page, and an abbreviated version on subsequent pages. 
65440A Implementation of a hardware-in-the-loop facility for student test and evaluation [6544-09] S. B. Mobley, G. Ballard, U.S. Army Aviation and Missile Command (USA); R. Brindley,

J. Gareri, Simulation Technologies, Inc. (USA)

\section{SESSION 3 HWIL COMPONENT TECHNOLOGY}

65440B Improving the fidelity of hydraulic flight motion simulators [6544-10]

M. L. Avory, R. L. Schneider, Ideal Aerosmith, Inc. (USA)

65440C Graphics processing unit (GPU) real-time infrared scene generation [6544-11]

C. L. Christie, E. Gouthas, O. M. Williams, Defence Science and Technology Organisation (Australia)

65440D Design tradeoffs in the development of the Advanced Multispectral Simulation Test Acceptance Resource (AMSTAR) HWIL facilities [6544-12]

K. G. LeSueur, Redstone Technical Test Ctr. (USA); F. J. Almendinger, Acutronic USA Inc. (USA)

65440E PC scene generation [6544-13]

J. A. Buford, Jr., D. Cosby, U.S. Army Aviation and Missile Research, Development and Engineering Ctr. (USA); D. H. Bunfield, A. J. Mayhall, D. E. Trimble, Davidson Technologies Inc. (USA)

\section{SESSION $4 \quad$ IR PROJECTION: ENABLING TECHNOLOGIES}

65440F Versatile plasma display technology for UV-visible scene projector [6544-15]

R. Ginn, S. Solomon, Acumen Scientific (USA); S.-J. Park, J. G. Eden, Univ. of Illinois at Urbana-Champaign (USA); J. Guy, E. Peters, Imaging Systems Technology (USA)

$65440 \mathrm{H}$ Is there life after thermal emitters? [6544-17]

V. Malyutenko, Lashkaryov Institute of Semiconductor Physics (Ukraine)

65440I Advances in 3D integration of heterogeneous materials and technologies [6544-18] D. Temple, J. M. Lannon, D. Malta, RTI International (USA); J. E. Robinson, P. R. Coffman, T. B. Welch, M. R. Skokan, DRS Infrared Technologies (USA); A. J. Moll, W. B. Knowlton, Boise State Univ. (USA)

65440K IR fiber sources for scene projection [6544-20]

L. B. Shaw, J. S. Sanghera, I. D. Aggarwal, Naval Research Lab. (USA)

65440L Multicolor IR emissive pixels [6544-22]

J. Lannon, S. Grego, RTI International (USA); S. Solomon, Acumen Scientific (USA)

Author Index 


\title{
Conference Committee
}

\author{
Symposium Chairs
}

John C. Carrano, Luminex Corp. (USA)

Larry B. Stotts, Defense Advanced Research Projects Agency (USA)

Program Track Chair

Gabor F. Fulop, Maxtech International Inc. (USA)

Conference Chair

Robert Lee Murrer, Jr., Millennium Engineering and Integration Co. (USA)

Conference Cochair

James A. Buford, Jr., U.S. Army Aviation and Missile Research,

Development and Engineering Center (USA)

Program Committee

Amenda Amick, U.S. Air Force (USA)

David B. Beasley, Optical Sciences Corp. (USA)

Paul T. Bryant, Left Coast Consulting (USA)

Charles F. Coker, Air Force Research Laboratory (USA)

David S. Cosby, U.S. Army Research, Development and Engineering Command (USA)

Naresh C. Das, Army Research Laboratory (USA)

George C. Goldsmith II, Air Force Research Laboratory (USA)

Alexander G. Hayes, MIT Lincoln Laboratory (USA)

Jay B. James, Santa Barbara Infrared, Inc. (USA)

John Lannon, RTI International (USA)

Heard S. Lowry, U.S. Air Force (USA)

Scott B. Mobley, U.S. Army Aviation and Missile Command (USA)

Randy A. Nicholson, Aerospace Testing Alliance (USA)

Robert M. Patchan, Johns Hopkins University (USA)

Donald R. Snyder, Air Force Research Laboratory (USA)

Steven L. Solomon, Acumen Scientific (USA)

Rhoe A. Thompson, Air Force Research Laboratory (USA)

Owen M. Williams, Defence Science and Technology Organisation (Australia) 


\section{Session Chairs}

1 Infrared Projector Device Design/Characterization/Optimization

George C. Goldsmith II, Air Force Research Laboratory (USA)

Heard S. Lowry, U.S. Air Force (USA)

2 HWIL Facilities

James A. Buford, Jr., U.S. Army Aviation and Missile Research,

Development and Engineering Center (USA)

Robert Lee Murrer, Jr., Millennium Engineering and Integration Co. (USA)

3 HWIL Component Technology

Amenda Amick, U.S. Air Force (USA)

Robert M. Patchan, Johns Hopkins University (USA)

$4 \quad$ IR Projection: Enabling Technologies

Naresh C. Das, Army Research Laboratory (USA)

Jay B. James, Santa Barbara Infrared, Inc. (USA)

Scott B. Mobley, U.S. Army Aviation and Missile Command (USA)

Steven L. Solomon, Acumen Scientific (USA) 